\title{
DISTRIBUTION, ABUNDANCE, AND GENETIC POPULATION STRUCTURE OF WOOD RIVER SCULPIN, COTTUS LEIOPOMUS
}

\author{
Kevin A. Meyer ${ }^{1,3}$, Daniel J. Schill ${ }^{1}$, Matthew R. Campbell2 ${ }^{2}$ and Christine C. Kozfkay²
}

\begin{abstract}
The Wood River sculpin Cottus leiopomus is endemic to the Wood River Basin in central Idaho and is a nongame species of concern because of its limited distribution. However, status and genetic population structure, 2 factors often central to the conservation and management of species of concern, have not been assessed for this species. We used backpack electrofishers to survey streams that were small enough (i.e., $<10 \mathrm{~m}$ wide) to collect quantitative distribution and abundance data for Wood River sculpin, and we used mitochondrial DNA control region sequencing to investigate the distribution of genetic variation across the species' range. Of the 102 study sites surveyed, 20 sites $(20 \%)$ had Wood River sculpin present, including $50 \%, 15 \%$, and $0 \%$ of the sites predicted a priori to contain, possibly contain, or not contain the sculpin, respectively. Native redband trout Oncorhynchus mykiss gairdneri were present at 21 study sites, including 18 of the 20 sites that contained Wood River sculpin. Sixty-one study sites $(60 \%)$ were dry or had too little water to contain any fish. We estimated that a minimum of 1.36 million Wood River sculpin ( $\geq 20 \mathrm{~mm}$ total length) currently reside in the basin. The presence of Wood River sculpin was positively associated with stream width:depth ratio and percent cobble/boulder substrate and negatively associated with stream gradient. Mitochondrial DNA haplotype differences were observed between and within the 3 major river subbasins supporting sculpin, with the most striking differences observed between populations in the Camas Creek subbasin and the other 2 subbasins, among which no haplotypes were shared, suggesting relatively long-term isolation. Our results suggest that the Wood River sculpin remains relatively widespread and abundant within its endemic range, despite obvious changes in historical stream connectivity caused by irrigation diversions and other chronic habitat alterations.
\end{abstract}

Key words: Cottidae, population status, occupancy, abundance, genetic population structure, conservation, endemic species.

The Wood River sculpin Cottus leiopomus is 1 of 8 sculpin species found in Idaho (Simpson and Wallace 1982). Although some of Idaho's sculpin species are widely distributed throughout the state, the Wood River sculpin is endemic only to the Wood River Basin, with 3 associated subbasins, the Big Wood River, the Little Wood River, and Camas Creek. The Wood River sculpin is a benthic species that inhabits flowing water, from small streams to large rivers, and is often found in sympatry with native redband trout Oncorhynchus mykiss gairdneri. The extent of this sympatry has not been investigated, but it likely occurs because of similar requirements of clean, cool water and coarse substrate (gravel and larger) for spawning and rearing of both species.

Wood River sculpin are recognized as a nongame species of concern by the Idaho Department of Fish and Game (IDFG 2006) because of their naturally restricted distribution and recent habitat fragmentation and alterations, the latter of which stem from irrigation diver- sions and reservoirs, floodplain encroachment, livestock grazing, and stream channelization. Despite the protected status of Wood River sculpin, little is known of the species' status or genetic population structure, 2 factors central to the conservation and management of native fish populations. In fact, to our knowledge, no publications exist on this species except a few unpublished agency reports. Although the Wood River sculpin is most likely a sedentary species like other stream-dwelling sculpin (McCleave 1964, Hill and Grossman 1987, Petty and Grossman 2004, Schmetterling and Adams 2004), the large number and size of irrigation withdrawals and diversions in the basin (Thurow 1988, Megargle 1999) could exacerbate the lack of population connectivity and threaten the existence of populations lower in the basin or at the lower end of streams.

In light of the scarcity of existing data for this species, the main objective of this study was to evaluate the current distribution and abundance of the Wood River sculpin throughout 

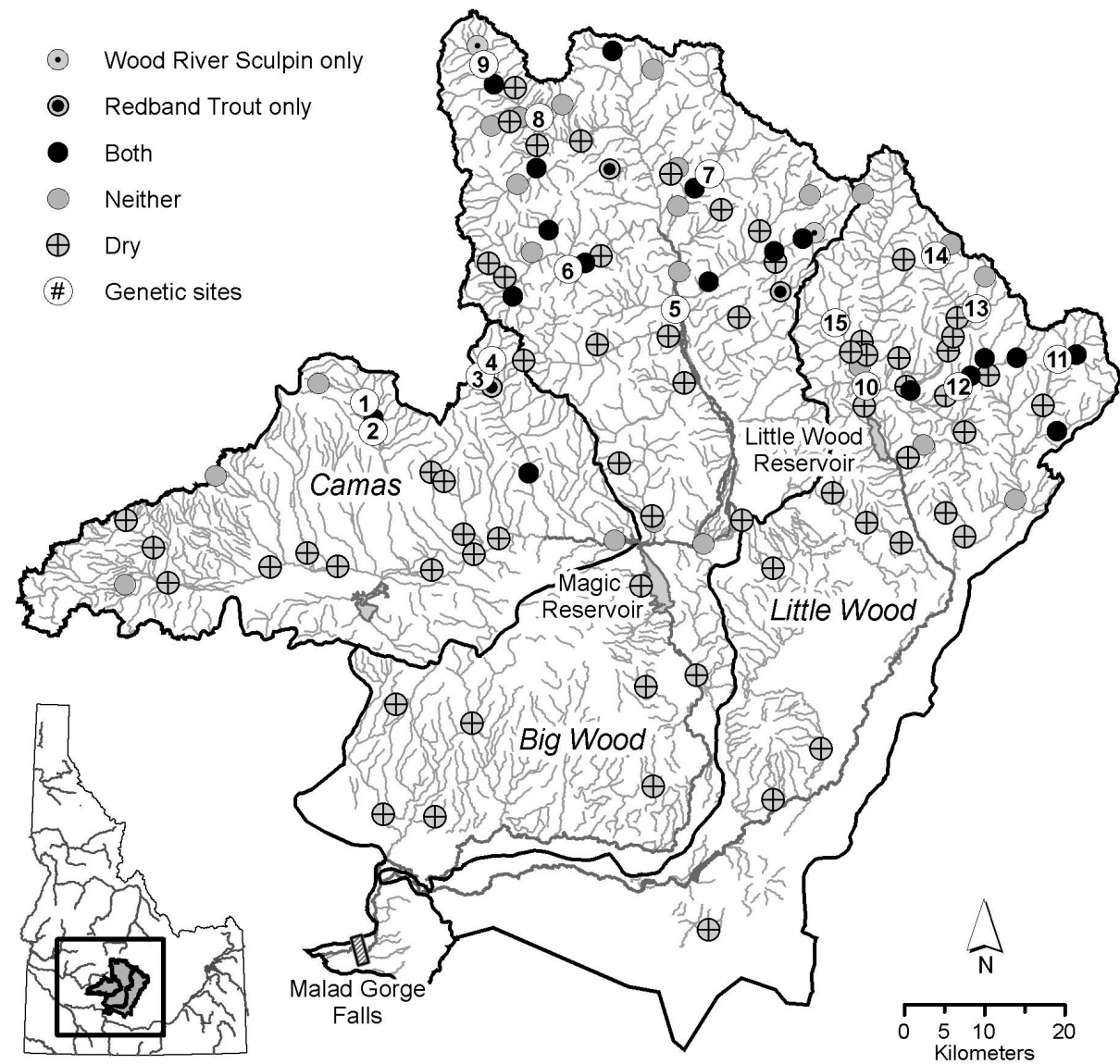

Fig. 1. Location of study sites where Wood River sculpin and redband trout were present or absent and where genetic samples were collected in 2003 in the Wood River Basin, Idaho. Numbers correspond to genetic sample locations in Table 5. Fifth-order and larger streams that were excluded from analyses (see methods) are shown as wider gray lines compared to other stream segments.

its historical range. To assess the extent of sympatry between Wood River sculpin and redband trout, we also collected distribution and abundance data on trout. We measured a variety of habitat conditions to assess what factors might influence the distribution and abundance of the Wood River sculpin across its range. Finally, we conducted a preliminary survey of the genetic structure of Wood River sculpin populations using mitochondrial DNA (mtDNA) data.

\section{Methods \\ Study Area}

The Wood River is a tributary of the Snake River in central Idaho, which is composed of 3 major subbasins: the Big Wood River, the Little Wood River, and Camas Creek. Historical processes of both volcanism and glaciation potentially contributed to the isolation of fish populations in the Wood River Basin. First, the basin is not directly connected with the Snake River because a 20-m waterfall known as Malad Gorge Falls is located about $5 \mathrm{~km}$ from the mouth and has created a long-term (i.e., tens of thousands of years) barrier to fish migration (Fig. 1). In addition, the Big Wood River was historically connected to the Little Wood River much farther up in the drainage through the present day Silver Creek Valley (Jankovsky-Jones 1997). It has only been since the late Quaternary Period, following a series of lava flows, dam creation, lake formation, 
and subsequent glacial deposition and dam breaching, that the Big Wood River changed to its present course and connection with the Camas Creek subbasin (Jankovsky-Jones 1997). Two dams with no fish passage further isolate fish within the basin (Fig. 1): Magic Reservoir in the Big Wood River subbasin (built in 1910) and Little Wood Reservoir in the Little Wood River subbasin (built in 1939).

The basin contains over $6000 \mathrm{~km}$ of stream covering $7778 \mathrm{~km}^{2}$ of semiarid valleys and mountainous headwaters that range from $837 \mathrm{~m}$ to over $3600 \mathrm{~m}$ in elevation. Vegetation includes western spruce-fir and pine forests at upper elevations and sagebrush steppe at low elevations. Precipitation is mostly in the form of winter snowpack and ranges from $18 \mathrm{~cm}$ in the lower valleys to $64 \mathrm{~cm}$ in the mountains. Discharge is driven by snowmelt and peaks between April and June, but it is modified by numerous irrigation diversions in mainstem and tributary streams. Native species in the Wood River Basin include Wood River sculpin, redband trout, mountain whitefish Prosopium williamsoni, bridgelip sucker Catostomus columbianus, largescale sucker Catostomus macrocheilus, Utah chub Gila atraria, longnose dace Rhinichthys cataractae, speckled dace Rhinichthys asculus, and redside shiner Richardsonius balteatus. Although Paiute sculpin Cottus beldingii have been reported from the lower Little Wood River (Merkley and Griffith 1993), their distribution is sparse, and it is unclear if they are native to the basin. Our samples did not contain any Paiute sculpin, which can be differentiated from Wood River sculpin by the presence of preopercular spines (Simpson and Wallace 1982). Introduced species that have established self-sustaining populations include brook trout Salvelinus fontinalis and brown trout Salmo trutta.

\section{Study Site Selection}

Data collection occurred from July to October 2003. Spatially balanced randomly selected study sites were generated with the help of the Environmental Protection Agency's Environmental Monitoring and Assessment Program (Fig. 1). The technique maps 2-dimensional space (in our study, a 1:100,000 scale hydrography layer) into 1-dimensional space with defined, ordered spatial addresses and uses restricted randomization to randomly order the spaces. Systematic sampling of the ran- domly ordered spaces results in a spatially balanced sample (Stevens and Olsen 2004). The study design and sampling frame was stratified in 2 ways to reduce overall variation in the abundance data and make estimates more accurate. First, all stream reaches were categorized a priori as either (1) likely to contain, (2) not likely to contain, or (3) possibly containing Wood River sculpin. This was based on professional knowledge of the geomorphology and anthropogenic alterations in the basin and on the suspected distribution of Wood River sculpin in the basin. Stream order (Strahler 1964) was used as a 2 nd stratification.

\section{Fish and Habitat Sampling}

At each study site, fish were captured using electrofishing gear. Depending on stream width, crews of 2-4 people performed multiple-pass electrofishing removals (2-4 passes) using 1 or 2 gas-powered backpack electrofishing units. Pulsed DC was used, with pulses of 3-5 ms, 500-900 volts, and 30-60 Hz. Sampling occurred during low to moderate flow conditions (i.e., after spring runoff and before the onset of winter) to facilitate effective fish capture and standardize sampling conditions. Block nets were placed at the lower and upper ends of the reach to prevent fish from moving out of the sampling reach during electrofishing.

All fish were retained, identified, and enumerated, but in our study streams, nongame species other than Wood River sculpin (i.e., longnose dace, speckled dace, redside shiner, and bridgelip sucker) were caught at fewer than 7 sites and thus were encountered too infrequently to include in our analyses. Consequently, only Wood River sculpin and trout data are reported herein. Fish were measured to the nearest millimeter (total length $=\mathrm{TL}$ ) and gram, and released. Study sites were typically ( $91 \%$ of the time) between 80 and $120 \mathrm{~m}$ in length (depending on habitat types, riparian vegetation, and our ability to place block nets) and averaged $96 \mathrm{~m}$ (range 45-130 m).

Maximum-likelihood abundance and variance estimates for Wood River sculpin and trout were calculated for each study site with the MicroFish software package (Van Deventer and Platts 1989). Wood River sculpin abundance estimates could not be obtained from large (i.e., >10 m in width; 5th-order streams and larger) mainstem reaches of the Wood River Basin. These reaches totaled $497 \mathrm{~km}$ in 
stream length (8\% of all stream kilometers) and were excluded from our analyses, despite the fact that sculpin and trout were often present in these reaches. Consequently, this study focuses only on the small $(<10 \mathrm{~m}$ in width) tributary streams and upper ends of the mainstem rivers.

Because electrofishing is known to be size selective (Sullivan 1956, Reynolds 1996), Wood River sculpin were separated into 2 length categories $(<60 \mathrm{~mm}$ TL and $\geq 60 \mathrm{~mm}$ TL), and trout were similarly separated into 2 length categories $(<100 \mathrm{~mm}$ TL and $\geq 100 \mathrm{~mm} \mathrm{TL})$. Abundance estimates were made separately for these size groups and summed for an overall estimate. Capture efficiencies for sculpin $<20 \mathrm{~mm}$ and for trout $<40 \mathrm{~mm}$ were especially low relative to larger fish; thus abundance values for sculpin $<60 \mathrm{~mm}$ and trout $<100 \mathrm{~mm}$ were probably underestimated (Peterson et al. 2004).

At each study site, we determined elevation (m) from U.S. Geological Survey 1:24,000 topographic maps using universal transverse mercator (UTM) coordinates obtained at the lower end of the reach that was electrofished. Stream order was determined from a 1:100,000 stream hydrology scale. Gradient (\%) was determined using the software package All Topo Maps, version 2.1 for Windows (iGage Mapping Corporation, Salt Lake City, UT); the distance (m) between the 2 contour lines that bounded the study site was traced (average traced distance was about $1 \mathrm{~km}$ ), and gradient was calculated as the elevational increment between those contours divided by the traced distance. We measured conductivity $\left(\mu \mathrm{S} \cdot \mathrm{cm}^{-1}\right)$ with a calibrated handheld conductivity meter accurate to $\pm 2 \%$. We noted land ownership as private or public.

Ten equally spaced transects were established within each study site, and from those transects, the remaining measurements were taken. Stream width $(\mathrm{m})$ was calculated from the average of all transect readings. At each transect, depth was measured at one-fourth, one-half, and three-fourths of the distance across the channel, and the sum of the measurements was divided by 4 to account for zero depths at the stream margins for trapezoidalshaped channels (Platts et al. 1983, Arend 1999). Percent substrate composition was visually estimated as the percent of substrate within $1 \mathrm{~m}$ of each transect that was silt $(<0.06 \mathrm{~mm})$, sand
(0.06-1.99 mm), gravel $(2-63 \mathrm{~mm})$, cobble (64$256 \mathrm{~mm}$ ), boulder (257-4096 mm), or bedrock (>4097 mm). The percentage of unstable banks and the percentage of stream shading were also visually estimated at each transect. We averaged all habitat measurements across all transects for an overall mean for each study site.

\section{Estimation of Fish Abundance}

We estimated total Wood River sculpin and trout abundances separately for each subbasin using the stratified random sampling formulas from Scheaffer et al. (1996). As previously mentioned, estimates were stratified by stream order (1st through 4th) and by a priori distribution categorization for sculpin and trout (i.e., likely present, likely absent, and unknown); thus, there were 12 strata $(L)$. We first summed the total length of stream within each stratum using the ArcView ${ }^{\circledR}$ geographic information system (GIS). The total number of sampling units in each stratum $\left(N_{i}\right)$ was calculated by dividing the stream length by our typical sampling reach length $(100 \mathrm{~m})$. Abundance estimates were standardized to density per 100 linear meters of stream. We calculated a mean abundance $\left(\bar{y}_{i}\right)$ within each stratum and an associated variance. For total population size $\left(N_{\text {census }}\right)$, we used the formula

$$
\left(N_{\text {census }}\right)=\sum_{i=1}^{L} N_{i} \bar{y}_{i},
$$

and for variance of $N_{\text {census }}$ we used the formula

$$
V\left(N_{\text {census }}\right)=\sum_{i=1}^{L} N_{i}{ }^{2}\left(\frac{N_{i}-n_{i}}{N_{i}}\right)\left(\frac{s_{i}{ }^{2}}{n_{i}}\right),
$$

where $s_{i}{ }^{2}$ is the variance of the observations in stratum $i$, and $n_{i}$ is the sample size within stratum $i$. From this we calculated $90 \%$ confidence intervals around the abundance estimates. All sample sites, including dry and fishless sites, were included in these estimates.

\section{Fish-Habitat Relationships}

We assessed whether stream characteristics that we measured were related to Wood River sculpin distribution and abundance. To do this we first removed all sites that were dry or had too little water to contain any fish. We then plotted all potential independent variables against presence-absence and abundance data in order to look for abnormalities and nonlinearity in 
the data. Both log and square-root transformations were needed to normalize the stream gradient data for comparison to presenceabsence and abundance data, respectively. Percent fine substrate could not be normalized with any data transformations and was therefore removed from further analyses. No other transformations were needed. Multicollinearity between independent variables was assessed with correlation analysis, but none was detected. Because width was used in the calculation of a standardized fish density metric (fish $\cdot \mathrm{m}^{-2}$ ), correlations between density and width or between density and width:depth ratio were not estimated.

To assess the relationship between stream attributes and the presence/absence of Wood River sculpin, we first calculated a mean and 95\% confidence interval for stream conditions with and without Wood River sculpin, with statistically significant differences determined by nonoverlapping confidence intervals (Johnson 1999). We then related stream attributes to Wood River sculpin occupancy using logistic regression analyses, adding stream attributes to the model in an iterative process and using Akaike's Information Criteria (AIC) to assess the best model. AIC is an extension of the maximum-likelihood principle with a bias correction term that penalizes for added parameters in the model (Akaike 1973). Lower AIC values indicate better-fitting models. For comparison we also calculated an adjusted $R^{2}$ for discrete models (Nagelkerke 1991). To assess the relationship between stream attributes and density of Wood River sculpin, we used multiple regression analyses, adding stream attributes to the model in an iterative process and using $R^{2}$ to assess the best model.

\section{Genetic Population Structure}

We chose mitochondrial DNA (mtDNA) analysis for this assessment because the high mutation rate, strict maternal inheritance, and low effective population size of mtDNA make it a useful tool for investigating the population structure of recently diverged or closely related taxonomic groups (Avise 1994). Additionally, the mtDNA control or "D-loop" gene region has already been successfully amplified and sequenced in several species of sculpin, and has demonstrated differences at the subbasin level between populations of fluvial sculpin Cottus nozawae (Yokoyama and Goto 2002) in
Japan, as well as shorthead sculpin Cottus confusus and mottled sculpin Cottus bairdi in Idaho (IDFG, unpublished data).

Ten to 22 nonlethal fin clips from Wood River sculpin (total $n=187$ ) were collected from 15 sample locations within the Wood River Basin (Table 5), but not necessarily the same locations as the fish abundance study sites (Fig. 1). Total genomic DNA was extracted from a $1 \times 1-m m$ piece of fin clip following methods described by Campbell (2000). DNA was resuspended in $100 \mu \mathrm{L}$ TE. Approximately 450 bp of the mtDNA control region were amplified in a $20-\mu \mathrm{L}$ reaction consisting of $1 \mu \mathrm{L}$ DNA extract (approximately $2.5 \mathrm{ng} \cdot \mu \mathrm{L}^{-1}$ ), 2.0 $\mu \mathrm{L} 10 \mathrm{X}$ buffer (Perkin Elmer), $2.0 \mu \mathrm{L} \mathrm{MgCl}_{2}$, $1.6 \mu \mathrm{L}$ bovine serum albumin, $1.0 \mu \mathrm{L}$ of each primer (L/5'-TTC CAC CTC TAA CTC CCA AAG CTA G-3' [Lee et al. 1995] and R/5'-CCT GAA GTA GGA ACC AGA TG-3' [Meyer et al. 1990]), $1.6 \mu \mathrm{L} 10.0 \mathrm{mM}$ dNTPs $(10 \mathrm{mM}$ each of dATP, dCTP, dGTP, and dTTP), $0.05 \mu \mathrm{L}$ Perkin-Elmer Taq polymerase, and $9.3 \mu \mathrm{L}$ $\mathrm{dH}_{2} \mathrm{O}$. Polymerase chain reaction conditions consisted of an initial denaturing cycle of $94^{\circ} \mathrm{C}$ for 3 minutes, followed by 32 cycles of denaturation at $94{ }^{\circ} \mathrm{C}$ for 45 seconds, annealing at 52 ${ }^{\circ} \mathrm{C}$ for 45 seconds, and extension at $72{ }^{\circ} \mathrm{C}$ for 1 minute, with a final extension at $72{ }^{\circ} \mathrm{C}$ for 3 minutes.

Sequencing reactions were performed with a BigDye Terminator Cycle Sequencing Ready Reaction Kit (Applied Biosystems, version 3.1, http://www3.appliedbiosystems.com) using both the forward and reverse primers. Sequenced products were cleaned using Edge BioSystems gel filtration plates (Edge Biosystems, http: //www.edgebio.com) and were run out on a Prism 3730 DNA sequencer (Applied Biosystems). Sequences were edited using Sequencher (Gene Codes Corporation, version 4.1.2, http://www.genecodes.com), and the consensus sequences (394 bp) were aligned using the Clustal W program (Thompson et al. 1994) within the software program MEGA3 (Molecular Evolutionary Genetics Analysis, version 3.0; Kumar et al. 2004).

Differences in mtDNA haplotype frequency distributions among the 3 major subbasins were tested for significance using a Monte Carlo chi-square simulation (Roff and Bentzen 1989). Sequence divergence ( $p$-distance) between haplotypes and a maximum-parsimony (MP) consensus tree depicting relationships between 
TABLE 1. Stream network (at the 1:100,000 scale) and distributional extent of Wood River sculpin (WRS) from study sites in 1st- to 4th-order streams sampled in 2003 within 3 subbasins of the Wood River, Idaho.

\begin{tabular}{|c|c|c|c|c|}
\hline Stream network and study sites & Big Wood River & Camas Creek & Little Wood River & Total \\
\hline Total stream km in Wood River drainage & 2847 & 1418 & 1738 & 6003 \\
\hline Stream $\mathrm{km}$ categorized a priori as "WRS present" & 244 & 60 & 211 & 515 \\
\hline Stream km categorized a priori as "WRS unknown" & 1455 & 470 & 746 & 2671 \\
\hline Stream km categorized a priori as "WRS absent" & 1148 & 888 & 781 & 2817 \\
\hline Total number of sites sampled & 52 & 15 & 35 & 102 \\
\hline Sites containing fish & 19 & 4 & 9 & 32 \\
\hline Sites within "WRS present" streams & 10 & 4 & 6 & 20 \\
\hline that contained WRS & 7 & 2 & 1 & 10 \\
\hline Sites within "WRS unknown" streams & 35 & 8 & 23 & 66 \\
\hline that contained WRS & 5 & 0 & 5 & 10 \\
\hline Sites within "WRS absent" streams & 7 & 3 & 6 & 16 \\
\hline that contained WRS & 0 & 0 & 0 & 0 \\
\hline Sites containing redband trout & 12 & 3 & 6 & 21 \\
\hline Dry or nearly dry sites & 29 & 9 & 23 & 61 \\
\hline
\end{tabular}

haplotypes were obtained from aligned sequences using MEGA3 (Kumar et al. 2004). The MP tree was obtained using the closeneighbor-interchange algorithm with search level 3, in which the initial trees were obtained with the random addition of sequences (100 replicates). All positions containing gaps and missing data were eliminated from the dataset (complete deletion option). To assess nodal strength, we performed 1000 bootstrap replicates. Since Paiute sculpin have been tentatively identified in the lower Little Wood River (Merkley and Griffith 1993) and resolved as a sister species to Wood River sculpin (Kinziger et al. 2005), we included a D-loop sequence from a Paiute sculpin (University of Alabama Ichthyological Collection [UAIC] 11528). We also included a D-loop sequence from a Wood River sculpin sample that had previously been sampled and sequenced (D.A. Neely unpublished data) from the Big Wood River and archived at the UAIC (11631). Two additional D-loop sequences from torrent sculpin Cottus rhotheus (UAIC 11670) and mottled sculpin Cottus hubbsi (UAIC 11633), collected in Idaho, were included for reference purposes (D.A. Neely, unpublished data).

\section{Results}

Wood River sculpin distribution and abundance was determined at 102 study sites in 1st- to 4th-order streams throughout the Wood River Basin, 61 of which were dry or had too little water to sustain any fish (Table 1). Fiftytwo of the study sites were on private property (65\% of which were dry or nearly dry), where- as 50 sites were on public land (52\% of which were dry or nearly dry).

The a priori categorization of Wood River sculpin distribution was reasonably accurate, given that sculpin were present at 10 of 20 sites $(50 \%)$ where we expected to find them, 0 of 16 sites where we expected them to be absent, and 10 of 66 sites (15\%) where we were unsure if they would be present (Table 1). Redband trout were found at 18 of 20 sites $(90 \%)$ where Wood River sculpin were found, and 3 of 82 sites (4\%) where Wood River sculpin were not found.

\section{Estimation of Fish Abundance}

Estimated abundance of Wood River sculpin in Idaho, including only 1st- through 4th-order streams, was $1,356,600 \pm 594,660$ (90\% confidence interval; Table 2). Forty-six percent of that abundance came from areas that were identified $a$ priori as likely to contain Wood River sculpin, whereas $54 \%$ of that abundance was estimated to be in streams where we were unsure if Wood River sculpin would be present. Comparatively, we estimated that there were $175,630 \pm 97,200$ redband trout in the Wood River Basin in 1st- through 4th-order streams (Table 2). Among all study sites (including those that were dry or had no fish), average linear abundance and areal density of Wood River sculpin were 0.40 individuals • $\mathrm{m}^{-1}$ and 0.09 individuals $\cdot \mathrm{m}^{-2}$, respectively. At only those sites where sculpin were present, average linear abundance and areal density were 2.04 individuals $\cdot \mathrm{m}^{-1}$ and 0.48 individuals $\cdot \mathrm{m}^{-2}$, respectively. 
TABLE 2. Estimated number of Wood River sculpin and redband trout present in 2003 in 1st- to 4th-order streams of the Wood River Basin, Idaho. Ninty-percent confidence intervals are given.

\begin{tabular}{|c|c|c|c|c|}
\hline Species & Size group & Occurrence category & $N_{\text {census }}$ & $90 \%$ confidence interval \\
\hline \multirow[t]{6}{*}{ Wood River sculpin } & \multirow[t]{3}{*}{$\geq 60 \mathrm{~mm}$} & Present & 402,313 & $89,977-714,652$ \\
\hline & & Absent & 0 & \\
\hline & & Unknown & 550,461 & $126,130-974,792$ \\
\hline & \multirow[t]{3}{*}{$<60 \mathrm{~mm}$} & Present & 226,533 & $24,915-428,151$ \\
\hline & & Absent & 0 & \\
\hline & & Unknown & 177,293 & $503-365,333$ \\
\hline TOTAL & & All & $1,356,600$ & $761,940-1,951,260$ \\
\hline \multirow[t]{6}{*}{ Redband trout } & \multirow[t]{3}{*}{$\geq 100 \mathrm{~mm}$} & Present & 55,175 & $14,044-96,306$ \\
\hline & & Absent & 0 & \\
\hline & & Unknown & 21,297 & $9427-33,167$ \\
\hline & \multirow[t]{3}{*}{$<100 \mathrm{~mm}$} & Present & 18,602 & $54-42,982$ \\
\hline & & Absent & 0 & \\
\hline & & Unknown & 80,556 & $156-164,346$ \\
\hline TOTAL & & All & 175,630 & $78,430-272,830$ \\
\hline
\end{tabular}

TABLE 3. Average stream conditions and associated confidence intervals (CIs) at sites with $(n=20)$ and without $(n=23)$ Wood River sculpin in the Wood River Basin, Idaho.

\begin{tabular}{lcrrr}
\hline & \multicolumn{2}{c}{ With Wood River sculpin } & \multicolumn{2}{c}{ Without Wood River sculpin } \\
\cline { 2 - 3 } Variable & Mean & $95 \%$ CI & Mean & $95 \%$ CI amplitude \\
\hline Stream order & 2.7 & 0.4 & 2.1 & 0.6 \\
Elevation $(\mathrm{m})$ & 1944.9 & 89.0 & 2010.4 & 171.9 \\
Gradient $(\%)$ & 2.5 & 0.8 & 6.6 & 3.3 \\
Conductivity $\left(\mu \mathrm{S} \cdot \mathrm{cm}^{-1}\right)$ & 220.0 & 55.0 & 207.0 & 55.0 \\
Width $(\mathrm{m})$ & 4.4 & 1.1 & 2.8 & 0.6 \\
Depth $(\mathrm{m})$ & 0.13 & 0.02 & 22.6 & 0.06 \\
W:D ratio & 32.5 & 4.8 & 1.4 & 0.7 \\
Percent fine substrate & 0.5 & 0.3 & 2.5 & 0.9 \\
Percent cobble/boulder substrate & 3.6 & 0.7 & 1.7 & 0.6 \\
Percent shading & 1.6 & 0.4 & 0.6 & 0.4 \\
Percent unstable banks & 0.5 & 0.4 & 0.05 & 0.10 \\
Redband trout density $\left(\right.$ number $\left.\cdot \mathrm{m}^{-1}\right)$ & 0.16 & 0.10 & & 0.10 \\
\hline
\end{tabular}

Fish-Habitat Relationships

At sites that contained enough water for fish to be present $(n=43)$, there appeared to be relationships between certain stream conditions and the distribution of Wood River sculpin (Table 3). Most notably, the likelihood of Wood River sculpin presence increased in a stream as width:depth ratio and percent cobble/ boulder substrate increased and gradient decreased (Fig. 2). The inclusion of all 3 variables in a logistic regression model gave the best AIC score (46.4) and explained 52\% of the total variation in Wood River sculpin occupancy (using the adjusted $R^{2}$ for discrete models). The next-best model was a 2 -variable model that included gradient and cobble/boulder substrate $(\mathrm{AIC}=49.5)$ and explained $41 \%$ of the variation in Wood River sculpin occupancy.
At sites that contained Wood River sculpin $(n=20)$, there was little correlation between any stream conditions and Wood River sculpin density (Table 4). Average depth was most strongly correlated to density, but inclusion of depth and stream order in a multiple regression model explained only $30 \%$ of the variation in Wood River sculpin density, whereas depth alone explained $28 \%$ of the variation in sculpin density. For redband trout, density was most positively correlated to percent stream shading and most negatively correlated to elevation (Table 4).

\section{Genetic Population Structure}

Seven haplotypes (unique DNA sequences) were observed in samples of Wood River sculpin (Table 5). Because previous sequencing in our lab of the D-loop mtDNA region in 


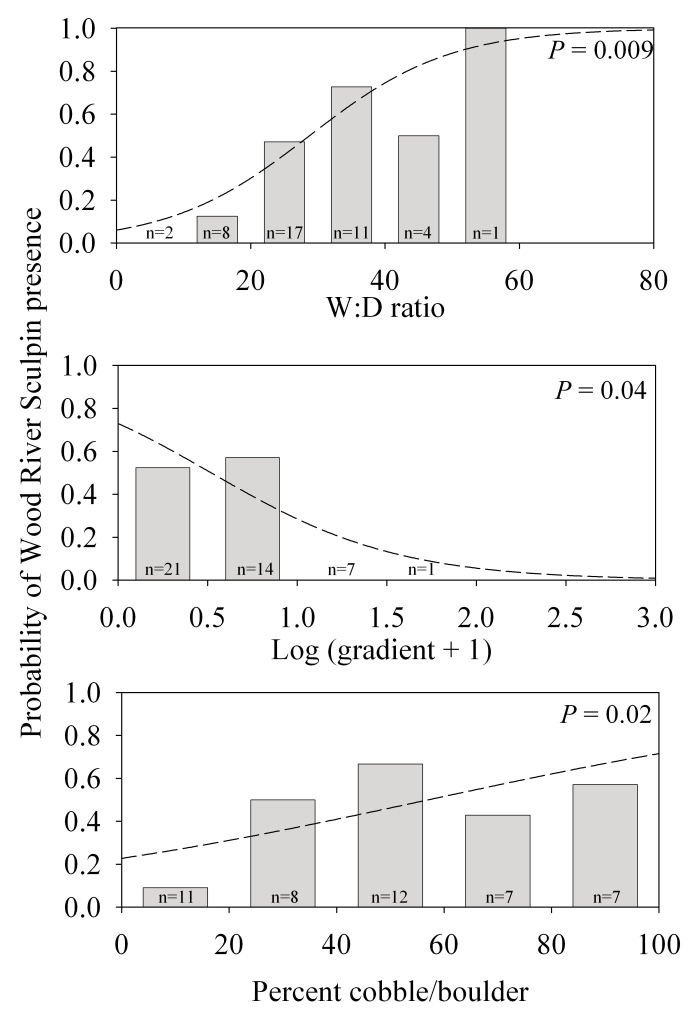

Fig. 2. Observed frequency of occurrence (histograms) and probability of occurrence predicted from logistic regression models (dashed lines) relating Wood River sculpin to stream conditions in the Wood River Basin, Idaho. The centers of the histograms are the midpoints of the bins used in the frequency distributions. $P$-values are from the combined logistic regression model that included all 3 stream variables (see text).

other sculpin species has yielded 13 haplotypes, the new haplotypes were labeled Cottus_14 through Cottus_20 (GenBank accession EU369333-EU3693352).

Statistically significant haplotype frequency differences were observed between the 3 subbasins $\left(P<0.005, \chi^{2}=197\right)$. The Cottus_14 haplotype was most common (66.3\%), occurring in all sample locations within the Big Wood and Little Wood river subbasins (Table 5). This haplotype was fixed within 8 of 11 sample locations in the Big Wood and Little Wood river subbasins and was the dominant haplotype in the other 3 locations. The Cottus_15, 16, and 20 haplotypes were present in the Big Wood River subbasin and Cottus_19 in the Little Wood River subbasin, but all 4 were found at low frequencies and only at sin-
TABLE 4. Correlations $(r)$ between stream attributes and density (fish $\cdot \mathrm{m}^{-2}$ ) of Wood River sculpin (WRS) and redband trout (RBT) at study sites surveyed in 2003 in the Wood River Basin, Idaho.

\begin{tabular}{lrr}
\hline & \multicolumn{2}{c}{ Density } \\
\cline { 2 - 3 } Stream attribute & WRS & RBT \\
\hline Gradient $(\%)$ & -0.30 & -0.12 \\
Stream order & 0.47 & -0.11 \\
Elevation $(\mathrm{m})$ & -0.16 & -0.35 \\
Conductivity $\left(\mu \mathrm{S} \cdot \mathrm{cm}^{-1}\right)$ & 0.22 & 0.13 \\
Depth $(\mathrm{m})$ & 0.53 & 0.07 \\
Percent cobble/boulder substrate & 0.23 & -0.20 \\
Percent unstable banks & -0.07 & -0.08 \\
Percent shading & 0.04 & 0.43 \\
Redband trout density & -0.01 & - \\
\hline
\end{tabular}

gle locations. In contrast, Cottus_14 was not observed within any of the sampling locations within the Camas Creek subbasin, where instead the most common haplotype was Cottus 17 (63.2\%). The Cottus 18 haplotype was also observed, but only in $\overline{2}$ sample locations in 1 stream. Sequence divergence between the 7 haplotypes observed within the Wood River Basin ranged from $0.3 \%$ to $1.0 \%$ (data not shown). Sequence divergence between these haplotypes and the reference Paiute sculpin sequence ranged from $5.9 \%$ to $6.4 \%$.

All haplotypes observed in the Wood River Basin and the reference Wood River sculpin sequence (UAIC 11631) clustered together in the MP consensus tree (84\% bootstrap support; Fig. 3). Within this group, there were no haplotypes that clustered together with greater than $50 \%$ bootstrap support. As expected, the reference Paiute sculpin sample (11528) grouped at a basal position to the Wood River sculpin samples (99\% bootstrap support).

\section{Discussion}

Our results suggest that Wood River sculpin are somewhat limited in distribution and reside in disconnected populations within their historical range in the Wood River Basin. In fact, Wood River sculpin were captured in $<20 \%$ of the study sites and were estimated to occupy only $11 \%$ of the 1st- through 4 th-order stream kilometers in the basin. Much of the reason for their meager distribution was that $60 \%$ of the sites we surveyed were dry or nearly dry during our sampling period. This arid condition is due in part to irrigation diversions over the last 150 years but also to natural hydrologic conditions common in the Wood River 
TABLE 5. Sample number (corresponding to Fig. 1) and location, polymorphisms (associated with each haplotype), haplotype, and haplotype frequency at genetic sample locations in the Camas Creek (CA), Big Wood River (BW), and Little Wood River (LW) subbasins in the Wood River Basin, Idaho.

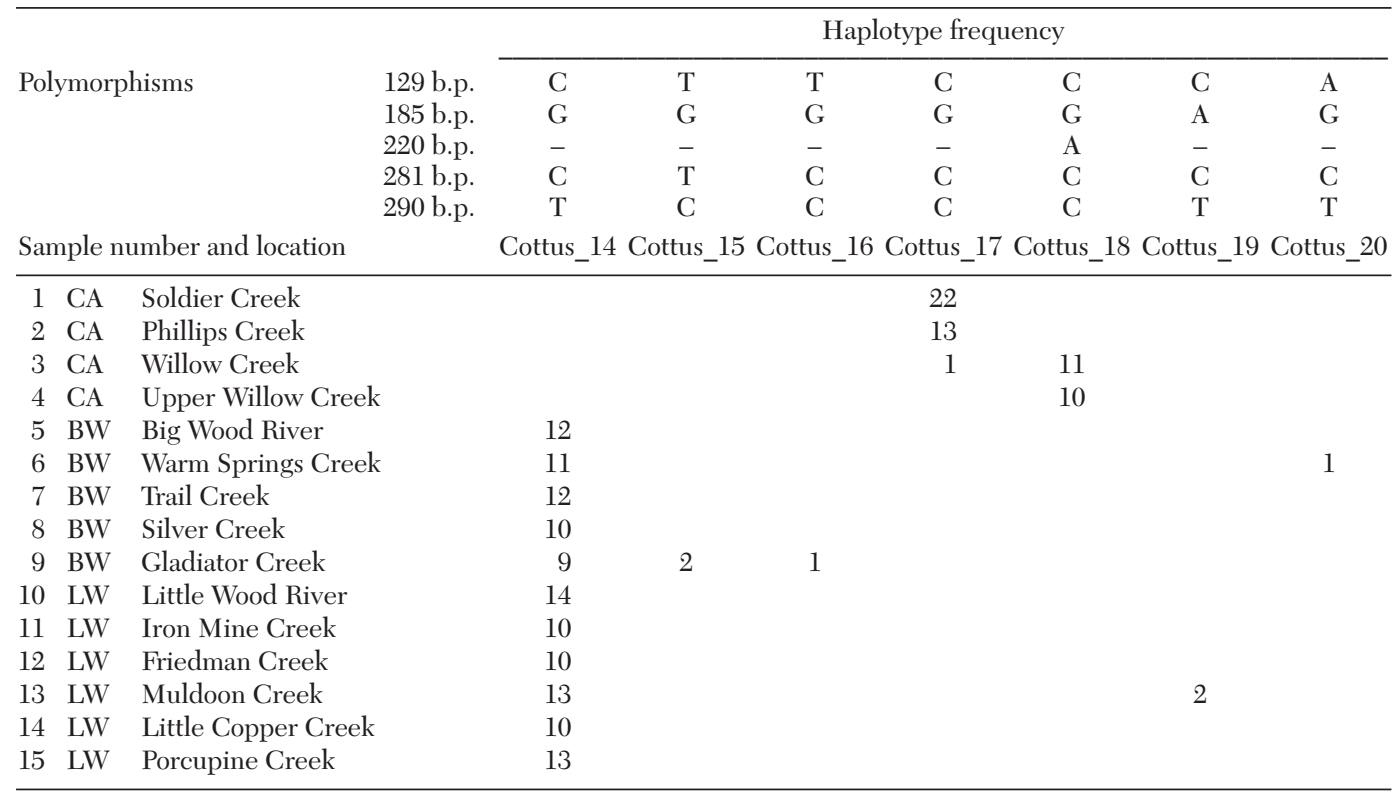

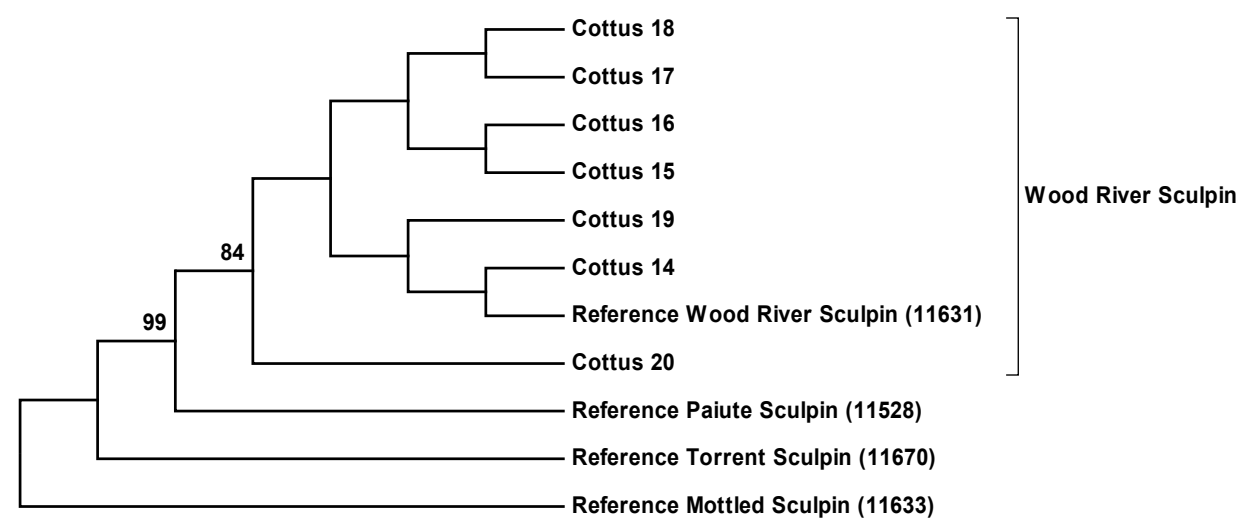

Fig. 3. Maximum-parsimony consensus tree of observed Wood River sculpin mitochondrial DNA haplotypes and 3 reference sequences. Bootstrap values (see text) are shown when $>50$.

basin (Castelin and Chapman 1972). Thus distribution and connectivity of fish in this basin was probably always naturally restricted at some level (see also Meyer et al. 2006), and it is difficult to estimate how much historical 1st- through 4th-order stream habitat is no longer occupied. There are some museum records of Wood River sculpin that reveal historical occupancy, but those we are aware of that were collected from locations downstream of their current extent of occupancy are limited to the mainstems of the Big Wood and Little Wood rivers.

Regardless of the exact historical distribution of Wood River sculpin, we found during our surveys that where flowing water was present in the basin, Wood River sculpin were also typically present and usually were quite abundant. For instance, at the 32 sites that supported at least 1 species of fish, Wood River 
sculpin were present $63 \%$ of the time. Moreover, they were nearly as widely distributed as and far more abundant than redband trout, which are considered to be robust in this basin (Thurow 1988). Although Wood River sculpin were over 7 times more numerous than redband trout, at sites where both were present, Wood River sculpin biomass averaged only $23.5 \mathrm{~kg} \cdot \mathrm{ha}^{-1}$ compared to $208.3 \mathrm{~kg} \cdot \mathrm{ha}^{-1}$ for redband trout. Previous studies have shown similar relationships between trout and sculpin density and biomass (Neves and Pardue 1983, Erman 1986).

Despite the somewhat restricted distribution of Wood River sculpin in the basin, several factors suggest that this is not indicative of a population at risk. First, true distribution and abundance were unavoidably underestimated in our study because sampling efficiency constraints in large river segments (i.e., 5th-order and higher) precluded inclusion of these segments, though sculpin were captured in many of these reaches when the reaches were sampled independently for salmonid populations (K. Meyer unpublished data). Second, depletion electrofishing typically underestimates both fish distribution (Bayley and Peterson 2001, Reynolds et al. 2003) and abundance (Riley and Fausch 1992, Peterson et al. 2004), especially for small fish such as sculpin. Furthermore, because of their sedentary nature, stream-dwelling sculpin already tend to naturally be fragmented into disconnected populations (Hill and Grossman 1987, Goto 1998, Petty and Grossman 2004). Not only were Wood River sculpin more abundant than redband trout, but compared to estimates for Yellowstone cutthroat trout $O$. clarkii bouvieri, another species of conservation interest in southern Idaho, Wood River sculpin were 5.5 times more abundant per square kilometer (cf. Meyer et al. 2006). Yellowstone cutthroat trout and Wood River sculpin have similar longevity, usually living to a maximum of 6 years of age, and both mature at between 2 and 4 years of age, but Wood River sculpin are far less fecund (see Meyer et al. 2003, 2008).

Wood River sculpin were almost always present when redband trout were present and almost always absent when redband trout were absent (Fig. 1), but it is unlikely that there was any causative effect between the species. In fact, at sites containing Wood River sculpin, their density and that of redband trout were not correlated $(r=-0.01)$, and habitat variables that were correlated to fish density were different between species. The most likely explanation is that both species require similar basic habitat requirements such as cold water for metabolic function and coarse substrate for spawning and rearing. Our results suggest that, once these basic needs are met, additional factors affecting distribution and abundance differ between the 2 species, as for other sympatric populations of salmonids and sculpin (e.g., Prenda et al. 1997, Inoue and Nakano 2001). Competition between sculpin and trout sometimes occurs (Brocksen et al. 1968, Hesthagen and Heggenes 2003, Ruetz et al. 2003), but habitat selection shifts can minimize potential competition between sculpin and trout (Prenda et al. 1997).

Few stream conditions we measured were strongly correlated to Wood River sculpin distribution or abundance. Nevertheless, considering their benthic nature and need for cobble/ boulder substrate for spawning and rearing, we were not surprised to find that Wood River sculpin were more likely to occur where gradient was low and cobble/boulder substrate was prevalent. Meyer et al. (2008) concluded that Wood River sculpin growth and survival also was inversely related to gradient. The fact that fish habitat models usually are region specific and difficult to transfer to areas outside the original study area (Fausch et al. 1988) is largely extraneous to this study, because Wood River sculpin exist only in the Wood River Basin. Nonetheless, our results should be viewed as introductory, and more research on habitat requirements and preferences for Wood River sculpin may further explain their current distribution and abundance. While numerous studies have identified specific habitat preferences for stream-dwelling sculpin (e.g., Brown 1991, van Snik Gray and Stauffer 1999, Inoue and Nakano 2001), others have concluded that microhabitat and macrohabitat conditions were of little importance and instead suggested that sculpin population dynamics were regulated most strongly by density-dependent processes such as competition for food and space (Petty and Grossman 1996, Grossman et al. 2006).

Results from this study indicate significant haplotype frequency differences both among and within the 3 major river subbasins supporting Wood River sculpin. The most striking 
difference was observed between the Camas Creek subbasin and the other 2 subbasins, in which no haplotypes were shared, although there was not clear phylogenetic support for this geographical subdivision. Significant genetic differences were also observed within the Camas Creek subbasin, with Willow Creek exhibiting a predominant haplotype not found in the other 2 sample locations. These results suggest that there is very limited gene flow between populations in the Camas Creek subbasin and populations in the Big Wood and Little Wood river subbasins. Similar conclusions can be drawn between Willow Creek and the other 2 sample locations within the Camas Creek subbasin.

Fewer genetic differences were observed between sample locations in the Big Wood and Little Wood river subbasins, with one haplotype dominant throughout these subbasins. Several additional haplotypes were also observed in low frequency within Gladiator Creek and Warm Springs Creek in the Big Wood River subbasin and in Muldoon Creek in the Little Wood River subbasin. While the majority of the sample locations in the Big Wood and Little Wood river subbasins shared the same haplotype, the lack of haplotype diversity within these subbasins prevented any conclusions from being drawn regarding current levels of gene flow among these populations. However, as previously mentioned, other species of sculpin have low dispersal distances (<50 m; Hill and Grossman 1987, Goto 1998, Petty and Grossman 2004) and exhibit restricted gene flow over short distances (Yokoyama and Goto 2002, Lamphere 2005), and it is likely that gene flow between populations of Wood River Sculpin within subbasins is similarly low.

There is no evidence to suggest that the differences observed between the Camas Creek subbasin and the other 2 subbasins were the result of sampling separate species of sculpin. This has been a concern in other drainages in Idaho where some sculpin species have been very difficult to distinguish morphologically (D. Zaroban, Albertson College Museum Fish Curator, personal communication). Sequencing of the mtDNA D-loop region in fluvial sculpin in Japan indicated that intraspecific sequence divergence at the basin level ranged between $0.6 \%$ and $1.8 \%$ (Yokoyama and Goto 2002). In our study, pairwise sequence divergence estimates among the 7 haplotypes observed in the
Wood River Basin were relatively low $(0.3 \%$ $1.0 \%)$ and similar in range to what we have observed at the basin level in other species of sculpin in Idaho (M.R. Campbell unpublished data). In contrast, sequence divergence between the reference Paiute sculpin sequence and the Wood River sculpin haplotypes was much higher $(5.9 \%-6.4 \%)$.

It is likely that a combination of other factors are responsible for the haplotype differences observed between the Camas Creek subbasin and the other 2 subbasins, including contemporary influences (dispersal behavior, population isolation as the result of anthropogenic influences, and population size) and historical processes. As mentioned previously, a review of the geological history of the Wood River Basin indicates that until the late Quaternary Period (1) the Camas Creek subbasin may have been isolated from both the Big Wood and Little Wood river subasins, and (2) the Big Wood and Little Wood river subbasins may have been directly connected. Both of these geological factors could have contributed to the fixed differences observed between populations in the Camas Creek subbasin and the other 2 subbasins.

In summary, the Wood River sculpin was the most abundant and one of the most widely distributed species of fish in 1st- to 4th-order streams in the Wood River Basin, being present in most locations (63\%) where any species of fish were present. Our genetic results provide some evidence of restricted gene flow among populations of Wood River sculpin, which is consistent with the life history and low dispersal of many species of streamdwelling sculpin. Obviously, natural and anthropogenic changes (drought and global warming, habitat alterations, and irrigation diversions) can exacerbate population fragmentation and isolation. The long-term consequences of population isolation (demographic and genetic) for this species will probably depend mostly on population size, which appears to be large, although highly variable, in many streams throughout the species' range. The stability of population size over time should be monitored. Initially, we suggest that any conservation monitoring and management efforts focus on the Camas Creek subbasin, because estimated abundance was lowest in this subbasin and sampled populations from this subbasin contained mtDNA diversity not found in the other 2 subbasins. 


\section{ACKNOWLEDGMENTS}

T. Olson and P. Larsen from the EPA provided invaluable assistance with the probability sampling design and site selection. T. Lamansky, J. Cassinelli, and L. Mamer were especially helpful in data collection and summarization. J. Chatel and D. Kenney with the Sawtooth National Forest provided funding for the genetic analyses. F. Partridge and J. Griffith provided helpful comments on an earlier draft of the manuscript.

\section{Literature Cited}

AKAIKE, H. 1973. Information theory and an extension of the maximum likelihood principle. Pages 267-281 in B.N. Petran and F. Csaki, editors, International symposium on information theory. 2nd edition. Akademiai Iadi, Budapest, Hungary.

Arend, K.K. 1999. Macrohabitat identification. Pages 7593 in M.B. Bain and N.J. Stevenson, editors, Aquatic habitat assessment: common methods. American Fisheries Society, Bethesda, MD.

Avise, J.C. 1994. Molecular markers, natural history, and evolution. Chapman and Hall, Inc., New York. 511 pp.

Bayley, P.B., and J.T. Peterson. 2001. An approach to estimate probability of presence and richness of fish species. Transactions of the American Fisheries Society 130:620-633.

Brocksen, R.W., G.E. Davis, and C.E. Warren. 1968. Competition, food consumption, and production of sculpin and trout in laboratory stream communities. Journal of Wildlife Management 32:51-75.

Brown, L.R. 1991. Differences in habitat choice and behavior among three species of sculpin (Cottus) in artificial stream channels. Copeia 1991:810-819.

CAMPBELL, M.R. 2000. Hybridization and introgression in a managed, native population of Yellowstone cutthroat trout: genetic detection and management implications. Master's thesis, University of Idaho, Moscow.

Castelin, P.M., And S.L. Chapman. 1972. Water resources of the Big Wood River, Silver Creek area, Blaine County, Idaho. Idaho Department of Water Administration, Water Information Bulletin 28, Boise.

Erman, D.C. 1986. Long-term structure of fish populations in Sagehen Creek, California. Transactions of the American Fisheries Society 115:682-692.

Fausch, K.D., C.L. Hawkins, and M.G. Parsons. 1988. Models that predict standing crop of fish from habitat variables: 1950-1985. General Technical Report PNW-GTR-213, USDA Forest Service, Portland, OR.

Goто, A. 1998. Life-history variations in the fluvial sculpin, Cottus nozawae (Cottidae), along the course of a small mountain stream. Environmental Biology of Fishes 52:203-212.

Grossman, G.D., R.E. Ratajczak, Jr., J.T. Petty, M.D. Hunter, J.T. Peterson, and G. Grenouillet. 2006. Population dynamics of mottled sculpin (Pisces) in a variable environment: information theoretic approaches. Ecological Monographs 76:217-234.

Hesthagen, T., and J. Heggenes. 2003. Competitive habitat displacement of brown trout by Siberian sculpin: the role of size and density. Journal of Fish Biology 62:222-236.

HiLl, J., and G.D. Grossman. 1987. Home range estimates for three North American stream fishes. Copeia 1987: 376-380.

[IDFG] Idaho Department of Fish and Game. 2006. 2007-2012 Fisheries management plan. Idaho Department of Fish and Game, Boise.

Inoue, M., AND S. NaKano. 2001. Fish abundance and habitat relationships in forest and grassland streams, northern Hokkaido, Japan. Ecological Research 16: 233-247.

JanKovsky-JonEs, M. 1997. Conservation strategy for Big Wood River Basin wetlands. Department of Fish and Game, Idaho Conservation Data Center, Boise. 30 pp.

Johnson, D.H. 1999. The insignificance of statistical significance testing. Journal of Wildlife Management 63:763-772

Kinziger, A.P., R.M. WoOd, AND D.A. NeEly. 2005. Molecular systematics of the genus Cottus (Scorpaeniformes: Cottidae). Copeia 2005:303-311.

Kumar S., K. Tamura, and M. Nei. 2004. MEGa3: integrated software for molecular evolutionary genetics analysis and sequence alignment. Briefings in Bioinformatics 5:150-163.

LAMPhERE, B.A. 2005. Movement and gene flow in an actively sedentary stream fish, the mottled sculpin (Cottus bairdi). Doctoral dissertation, University of North Carolina at Chapel Hill.

Lee, W.J., J. Conroy, W.H. Howell, and T.D. Kocher. 1995. Structure and evolution of teleost mitochondrial control regions. Journal of Molecular Evolution 41:54-66.

McCleave, J.D. 1964. Movement and population of the mottled sculpin (Cottus bairdi Girard) in a small Montana stream. Copeia 1964:506-513.

Megargle, D.J. 1999. Irrigation diversion fish loss reduction. Annual Progress Report, Grant F-73-R-21, Project 7. Report Number 00-02, Idaho Department of Fish and Game.

Merkley, K., And J.S. Griffith. 1993. Densities and habitat utilization of Wood River sculpin (Cottus leiopomus) on three Nature Conservancy preserves in Idaho. Final report to the Nature Conservancy, Field office, Hailey, ID.

Meyer, A., T.D. Kocher, P. Basasibwaki, and A.C. Wilson. 1990. Monophyletic origin of Lake Victoria cichlid fishes suggested by mitochondrial DNA sequences. Nature 347:550-553.

Meyer, K.A., J.D. Cassinelli, and F.S. Elle. 2008. Life history characteristics of the Wood River sculpin, Cottus leiopomus, in Idaho. Copeia 2008:648-655.

Meyer, K.A., D.J. Schill, F.S. Elle, and J.A. Lamansky, JR. 2003. Reproductive demographics and factors that influence length at sexual maturity of Yellowstone cutthroat trout in Idaho. Transactions of the American Fisheries Society 132:183-195.

Meyer, K.A., D.J. Schill, J.A. Lamansky, JR., M.R. CampBELL, AND C.C. KozFKay. 2006. Status of Yellowstone cutthroat trout in Idaho. Transactions of the American Fisheries Society 135:1329-1347.

NAGELKERKE, N.J.D. 1991. A note on a general definition of the coefficient of determination. Biometrika 78: 691-692.

Neves, R.J., AND G.B. Pardue. 1983. Abundance and production of fishes in a small Appalachian stream. 
Transactions of the American Fisheries Society 112: $21-26$.

Peterson, J.T., R.F. Thurow, and J.W. Guzevich. 2004. An evaluation of multipass electrofishing for estimating the abundance of stream-dwelling salmonids. Transactions of the American Fisheries Society 133: $462-475$.

Petty, J.T., And G.D. Grossman. 1996. Patch selection by mottled sculpin (Pisces: Cottidae) in a southern Appalachian stream. Freshwater Biology 35:261-276.

2004. Restricted movement by mottled sculpin (Pisces: Cottidae) in a southern Appalachian stream. Freshwater Biology 49:631-645.

Platts, W., W. Megahan, and G. Minshall. 1983. Methods for evaluating stream, riparian, and biotic conditions. General Technical Report INT-138, USDA Forest Service, Ogden, UT.

Prenda, J., P.D. Armitage, and A. Grayston. 1997. Habitat use by the fish assemblages of two chalk streams. Journal of Fish Biology 51:64-79.

ReynOlds, J.B. 1996. Electrofishing. Pages 221-254 in B. Murphy and D. Willis, editors, Fisheries techniques. 2nd edition. American Fisheries Society, Bethesda, MD.

Reynolds, L., A.T. Herlihy, P.R. Kaufmann, S.V. GreGORY, AND R.M. Hughes. 2003. Electrofishing effort requirements for assessing species richness and biotic integrity in western Oregon streams. North American Journal of Fisheries Management 23:450-461.

Riley, S.C., AND K.D. Fausch. 1992. Underestimation of trout population size by maximum-likelihood removal estimates in small streams. North American Journal of Fisheries Management 12:768-776.

Roff, D.A., AND P. BENTZEN. 1989. The statistical analysis of mitochondrial DNA polymorphism: X2 and the problem of small samples. Molecular Biology and Evolution 6:539-545.

Ruetz, C.R., III, A.L. Hurford, and B. Vondracek. 2003. Interspecific interactions between brown trout and slimy sculpin in stream enclosures. Transactions of the American Fisheries Society 132:611-618.

Scheaffer, R.L., W. Mendenhall, and L. Ott. 1996. Elementary survey sampling. 5th edition. Duxbury Press, Belmont, CA.
Schmetterling, D.A., And S.B. Adams. 2004. Summer movements within the fish community of a small montane stream. North American Journal of Fisheries Management 24:1163-1172.

Simpson, J.C., and R.L. Wallace. 1982. Fishes of Idaho. University of Idaho Press, Moscow.

Stevens, D.L, JR., And A.R. Olsen. 2004. Spatially balanced sampling of natural resources. Journal of the American Statistical Association 99:262-278.

Strahler, A.N. 1964. Quantitative geomorphology of drainage basins and channel networks. Section 4-2 in V.T. Chow, editor, Handbook of applied hydrology. McGraw-Hill, New York.

Sullivan, C. 1956. The importance of size grouping in population estimates employing electric shocking. Progressive Fish-Culturist 18:188-190.

Thompson, J.D., D.G. Higgins, and T.J. Gibson. 1994. CLUSTAL W: improving the sensitivity of progressive multiple sequence alignment through sequence weighting, position specific gap penalties and weight matrix choice. Nucleic Acids Research 22:4673-4680.

Thurow, R.F. 1988. Effects of stream alterations on rainbow trout in the Big Wood River, Idaho. 68th Annual Conference of the Western Association of Fish and Wildlife Agencies, Albuquerque, NM.

Van Deventer, J., and W.S. Platts. 1989. Microcomputer software system for generating population statistics from electrofishing data - user's guide for MicroFish 3.0. General Technical Report INT-254, USDA Forest Service, Intermountain Research Station, Ogden, UT.

van Snik Gray, E., and J.R. Stauffer, Jr. 1999. Comparative microhabitat use of ecologically similar benthic fishes. Environmental Biology of Fishes 56:443-452.

Yokoyama, R., AND A. Goto. 2002. Phylogeography of a freshwater sculpin, Cottus nozawae, from the northeastern part of Honshu Island, Japan. Ichthyological Research 49:147-155.

Received 17 January 2008 Accepted 4 June 2008 